\title{
Retail City: The Relationship between Place Attractiveness and Accessibility to Shops
}

\author{
Özge Öner
}




\title{
RETAIL CITY
}

\section{The relationship between place attractiveness and accessibility to shops}

\author{
Özge Önera, b
}

\begin{abstract}
This paper explores the role of retailers as an urban amenity. Using data for Swedish rural and city municipalities for 2002-2008, 'accessibility to shops' measures are constructed for the shops in the municipalities and in the hosting regions separately to examine the relationship between consumption possibilities and place attractiveness in a spatial continuum. Place attractiveness is proxied by a $\mathrm{Q}$ ratio for Swedish housing investment based on Tobin's Q. Access to stores within municipal market boundaries is found to be relevant for the place attractiveness of city municipalities, whereas no such relationship is evident for rural municipalities.
\end{abstract}

Keywords: Housing, Urban amenities, Retail, Q theory, Regional hierarchy

JEL codes: L81, R12, R31, R14

The author wish to thank Handelns Utvecklingsråd (The Swedish Retail and Wholesale Development Council), and the Jan Wallender and Tom Hidelius Foundation for financial support.

a Research Institute of Industrial Economics (IFN), P.O. Box 55665, SE-10215 Stockholm, Sweden

b Centre for Entrepreneurship and Spatial Economics, Jönköping International Business School, Gjuterigatan 5 Building B, SE-55111, Jönköping, Sweden

E-mail: ozge.oner@ifn.se 


\section{Introduction}

The traditional approach views urban and rural development as the consequence of spatial distribution and uses of the traditional factors of production (land, labor and capital). This approach is challenged by relatively recent studies. Such studies emphasize the importance of consumption possibilities and urban amenities to the growth and development of cities and regions (LLOYD and CLARK, 2001; CLARK et al., 2002; CLARK, 2003a, 2003b). Urban public authorities and actors in the private sector have begun to focus their attention on enhancing the attractiveness of their location to attract future residents, tourists, conventioneers, and retail consumers. It is argued that as firms and individuals become more mobile, the role of consumption possibilities in a city grows, forming an attractive attribute (GLAESER et al., 2001).

The paper aims to address the relevance of consumption possibilities to the attractiveness of a place, with a focus on the role of retail shops as an urban amenity. The paper also presents an empirical exercise addressing spatial equilibrium in an open city system. The theoretical framework for a static spatial equilibrium across cities suggests that (in equilibrium) housing prices should reflect people's willingness to reside in a place and should be explained by wage levels under the assumption that all places offer identical opportunities to their residents (e.g., ROBACK, 1982). But previous research shows that in some cities housing prices increase more rapidly than wage levels (GLAESER, 2001). This finding implies that people are willing to pay a premium for certain locations with respect to how much money they earn. As argued in the Rosen-Roback framework, amenities capture most of the unobserved characteristics that drive the variations in average house prices. In this strand of literature, high-amenity cities are found to grow and develop faster than low-amenity cities. Building on this idea, this paper argues for the importance of the retail sector as an urban amenity. The paper also presents an empirical application that examines the relevance of the retail sector to place attractiveness.

In addition to the multipronged discussion of place attractiveness and consumption possibilities, this paper offers two particular empirical novelties. First, the paper utilizes an 'accessibility to shops' measure that allows for an investigation of the available shops in the local market and in the region separately. The measure accounts for consumption possibilities not only in the immediate surroundings of a municipality but also in the hosting region, which then facilitates a discussion of spillover effects and the spatial continuum. Through the orthogonalization of such measures against market size, the relevance of retail shop availability to place attractiveness is discussed, beyond the sheer scale effects arising from the pertinent local economy. The second novelty in the empirical exercise lies in how place attractiveness is depicted. The quantification of the attractiveness of a place and the comparison across several places are onerous tasks. A standard theoretical framework may suggest examining average house prices, as they are acknowledged to reflect the relative demand for residence in a particular city municipality, thus representing a plausible alternative to capturing the relative degree of place attractiveness. The empirical application takes one further step and uses a Q ratio for housing investments in Swedish municipalities, 
constructed based on Tobin's transparent Q theory. Using average house prices on the municipal level may be problematic because the cost of construction could vary across space as housing prices do. By contrast, using the $\mathrm{Q}$ ratio allows for capturing excess supply (or demand) for housing and thus accounting for variation in production costs. The empirical practice also isolates the effect of timeinvariant assets that contribute to place attractiveness (such as natural amenities, historical monuments, climate and coastal borders) by fixed-effect estimations using Swedish data on the municipal level for the years 2002-2008, and the work further controls for the scale of the market, the concentration of leisure services, tax levels and overall labor market conditions. The conversation on place attractiveness and consumption possibilities is also extended to capture the variation across (i) city and (ii) rural municipalities in the empirical design. The results are consistent with a significant relationship between access to shops in the region and place attractiveness in both city and rural municipalities, with the relationship being notably stronger for the first. The relationship between access to shops in close proximity and place attractiveness is evident only in the city municipalities, but this relationship is not evident in the rural parts of the country.

\section{Background and motivation}

\subsection{Retail and place attractiveness}

Amenities can be broadly defined as place-specific assets that are known to contribute to a city's or region's attractiveness. Their importance for regional growth and development is emphasized in detail by a large body of literature (ROSEN, 1979; ROBACK, 1982; ULLMAN, 1954; BRUECKNER et al., 1999; GLAESER et al., 2001; CLARK et al., 2002; CLARK; 2003b). Places with attractive assets are found to attract highly skilled individuals (JACOBS, 1961; BRUECKNER et al., 1999; FLORIDA et al. 2008). A concentration of amenities, arts and culture is found to be relevant to population growth and development in both central markets and peripheral locations (PARTRIDGE et al., 2008; MELLANDER et al., 2011).

What are the pillars of place attractiveness? The aspects associated to place attractiveness can perhaps be summarized based on a few essential elements of a city, such as its architecture, cultural infrastructure, labor market, public services, service sector, and shops. Some of the elements are intrinsic to a place, whereas other elements relate to the size of the market and externalities. Geographic proximity to these elements elevates the quality-of-life aspect of places. In that sense, it is likely that the most important aspect of cities is that they provide individuals with a capacity for social interaction through increased access to people ${ }^{1}$, consumer amenities and other types of cultural and historical amenities. In that sense, a city (or town) itself can be considered to be a territorial public good, as is proposed by Andersson and Andersson (2006). The urban amenity premium is discussed in the previous literature, which finds the

\footnotetext{
1 Access to people is essential for interaction between individuals as well as between economic agents, and is crucial for network development (ANDERSSON and KARLQVIST, 1976; LUCAS, 2001).
} 
assets of cities to contribute to place attractiveness and housing values (DES ROSIERS et al., 2000; GLAESER et al., 2005).

How is retail relevant to the consideration of place attractiveness? Can we acknowledge retail as an important amenity in cities or regions? Historically, we have experienced a drastic increase in leisure time in advanced nations. Data from many countries show an increase in the share of disposable income that is allocated to the consumption of leisure goods and services (ANDERSSON and ANDERSSON, 2006). With the increased mobility of individuals, the demand for amenities and quality-of-life attributes in space has increased accordingly (GRAVES and LINNEMAN, 1979; CLARK, 2003a). The importance of the increase in leisure expenditures to the entire retail sector is undeniable. For example, Krafft and Mantrala (2006) emphasize that changing consumer needs and increasing interest in the shopping experience have altered the retailing landscape in the $21^{\text {st }}$ century. The role of retailers as the providers of goods for utilitarian purposes has become more complex following consumers' increasing appreciation for diverse consumption possibilities in space (RIVERA-BATIZ, 1988). Shops and other consumer services differ from natural amenities in that sense because they are highly related to the economic performance of cities and agglomerative forces. Recent empirical studies show that urban density facilitates consumption, and cities with urban amenities have grown faster than low-amenity cities (GLAESER, 2001).

Considering the amenity role of retailers for place attractiveness requires one to account for not only the presence of stores, but also the 'accessibility' to these stores. In this line of thinking, the benefits from retailers are derived not only from the utility that one derives from the actual shopping, but also from the indirect effects a certain scale of retail market in close proximity. The presence of stores in a market is primarily driven by the size of the market in terms of the potential demand in the immediate surroundings. However, stores serve not only the residents in close proximity but also consumers travelling from other market locations. Such demand inflow should thus have a multiplier effect for a city; hence, the effect of retailing on the overall economy and attractiveness of a town can extend beyond the linear relationship between the sector and the size of the respective domestic market. Thus, for a consumer, the relevant retail market nearly always extends beyond the politically defined boundaries of the town in which the individual lives.

Shops are like public goods, mimicking a historical monument or a park, in terms of contributing to place attractiveness. A consumer does not always need to purchase an item at a given store to enjoy the beautifully displayed shop windows. The vibrant environment provided by the presence of a retail cluster fosters increased interaction in space, which is itself an asset. The concentration of shops in a market attracts visitors from other places (similar to touristic attractions), which has a multiplier effect for the overall local economy. The idea of retailers acting as quasi-public goods requires one to revisit the fundamentals of 'public goods'. In the Tiebout (1956) framework, rational individuals are expected to leave places with less attractive local public goods and move to places with more attractive local public goods. Individuals 'vote with their feet' by migrating to places with more attractive attributes associated 
with local public goods. For goods to be defined as pure public goods, such goods should be consumed without rivalry or exclusion. But in the case of shops, distance (accessibility) serves as an exclusionary force because a consumer needs to be located within a certain proximity to enjoy the presence of a shop, either directly by consumption, or indirectly via its aforementioned contributions to place attractiveness. Some shops, on the other hand, can serve as disamenities. A dwelling close to a large, crowded discount store can have an aversive effect on people's willingness to pay for it.

\subsection{Spatial Externalities}

Spatial externalities are closely tied to the attractiveness of places, and their influence is reflected in the housing market. The depth and breadth of consumer amenities, natural amenities, opportunities in the labor market, and natural and cultural assets attract households to the hosting town or region. Consequently, increased demand for residential space in these places results in higher prices in the housing market (RIVIERA-BATIZ, 1988; BRUECKNER et al., 1999).

Housing prices are primarily affected by proximity to urban nodes, where agglomerative forces ${ }^{2}$ provide individuals with several advantages. For example, densely populated areas relate to greater access to larger job markets with a possible urban wage premium and better labor market matching (GLAESER and MÁRE, 1994; CICCONE and HALL, 1996; HELSLEY and STRANGE, 1990; ANDERSSON et al., 2013; LARSSON, 2014). Not only jobs but also nearly all economic activities are distributed across space in a systematic manner. Location theories addressing the systematic variation in the spatial distribution of economic activities date back to von Thunen (1826). Transportation costs (depending on the distance to the central market) are proposed to be the main determinant of how economic activities with varying interaction intensity are distributed across space, which results in varying land prices. Theories of size and density for urban areas have been further developed by several location theorists following this essential idea (WEBER, 1909; CHRISTALLER, 1933; LÖSCH, 1954; ISARD, 1956; BECKMANN, 1958; ALONSO, 1964).

Proximity to the central marketplace and the resulting economic density are important components of place attractiveness. However, the precise identification of what makes a place attractive is a fairly complex task. Some of the attractive assets of a place relate to natural amenities such as open space, parks and green areas, urban forest, farmlands and water covers, which are found to contribute to the location premium that is reflected in housing prices (CHESHIRE and SHEPPARD, 1995; TYRVÄINEN and MIETTINEN, 2000; IRWIN, 2002; ANDERSSON and WEST, 2006; GIBBONS et al., 2011). The earlier literature argues that the spatial heterogeneity in housing prices can -at least to some extent- be explained by these types of local 'open space amenities' (GEOGHEGAN et al., 1997; CHO et al., 2008). However, most of the amenities that are not intrinsic to locations are the products of agglomerative forces

\footnotetext{
2 The concept of 'agglomeration economies' is introduced in the research of Marshall (1890), who emphasizes the gains from shared inputs and mutual interaction.
} 
and density in space. The agglomeration of private and public services (and goods) is acknowledged to be one of the most important determinants of the variation in housing prices across cities as well as across countries (DUBIN and SUNG, 1987; ANDERSSON, 1997; ADAIR et al., 2000; SÖDERBERG and JANSSEN, 2001; ANDERSSON et al., 2010).

From the household and individual consumer perspective, there are several gains associated with agglomerative forces that also relate to the importance of urban amenities for place attractiveness. RiveraBatiz (1988) notes that a greater variety in local goods and the consumption of traded goods have a substantial influence on household utility. The provision of public goods and services is also found to be subject to less friction in places with a high degree of localized spillovers (ARTLE, 1959; ANDERSSON, 1985).

\subsection{Spatial equilibrium across cities}

The rationale behind the empirical exercise in this paper is derived from a static spatial equilibrium framework (see ROBACK, 1982), which is extended further to investigate the relevance of accessibility to shops on place attractiveness (reflected in the Q ratio for housing investment). The spatial equilibrium approach has three distinct equilibrium conditions for residents, employers and builders. One of the assumptions for spatial equilibrium across cities is that individuals must be making optimal choices with regard to their location. Most of the models that address spatial equilibrium across cities assume a single type of individual, which implies that the utility levels across space must be identical ${ }^{3}$.

One of the differences between within-city and across-city spatial equilibrium is that we assume wage levels to be constant in the first approach, whereas we acknowledge wage differentials across cities in the second approach. As Glaeser (2008) notes, although productivity differences across space have a great influence on labor demand, for the sake of simplicity, labor demand can be considered exogenous rather than endogenous. In the Rosen-Roback framework for static spatial equilibrium across cities, housing prices are explained by wage levels and by the amenities that are present (ROSEN, 1979; ROBACK, 1982). Roback (1982) discusses how workers are distributed across locations with varying amenities and how this distribution is reflected in wages and housing prices. A representative worker ${ }^{4}$ maximizes utility subject to a budget constraint as follows:

$\max U\left(x, l^{c} ; s\right)$ subject to $w+I=x+l^{c} r$

where $S$ is the quantity of amenities in his location, $x$ is the composite commodity consumed and $l^{c}$ is housing (residential land) consumed. In the equation, $w$ denotes the wages, $I$ denotes non-labor income, and $r$ represents the rental payments.

\footnotetext{
${ }^{3}$ The assumption of more than one type of individual makes the computation of equilibrium problematic (see GLAESER, 2008 for further discussion).

${ }^{4}$ All consumers (workers) are assumed to be identical in tastes and skills, and the amount of labor supplied by each unit of labor is assumed to be independent of the wage.
} 
The indirect utility function ${ }^{5}, \mathrm{~V}$, is thus the following:

$V(w, r ; s)=k$

This equation implies that wages and rents must be different across cities with varying quantities of amenities to equalize the individual utility in these cities.

The second component of the equilibrium is on the firm's (employer's) side, represented by a production function $^{6}, X=f\left(l^{p}, N ; s\right)$, which consists of $l^{p}$, land used in production, and $N$, the total number of workers in a city ${ }^{7}$. The equilibrium condition for firms is thus the following ${ }^{8,9}$ :

$C(w, r ; s)=1$

Equations 2 and 3 in this framework determine wages $(w)$ and rents $(r)$ as functions of the amenities in place $(s)$. The equations indicate that wages and rents (housing values) can be determined by the interaction of the equilibrium conditions for firms and consumers (or workers), which are the two sides of the market ${ }^{10}$.

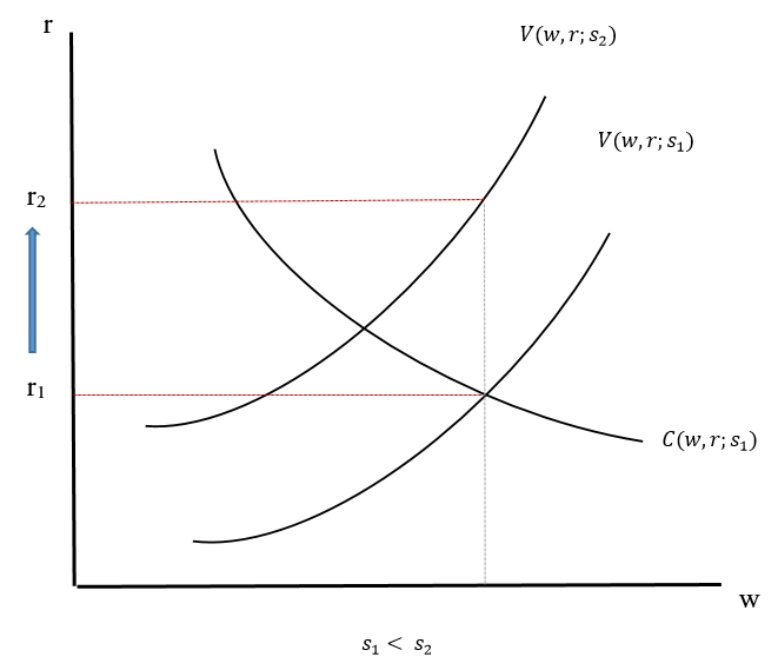

Figure 1: Spatial equilibrium for firms and individuals in places with varying amenities

Figure 1 above (adapted from ROBACK, 1982) shows the effect of different quantities of amenities in space on wages and rents. The argument is that high rents discourage both firms and workers from being located in an area. Worker equilibrium requires high rents in high-amenity areas to inhibit immigration,

\footnotetext{
${ }^{5} \partial V / \partial s>0$ because $s$ is an amenity.

${ }^{6}$ Constant returns-to-scale production function

${ }^{7}$ By assumption, capital is perfectly mobile; thus, it is uninfluenced by amenities. Therefore, the returns to capital will be equal in all places. For this reason, capital is not included in the optimization.

${ }^{8}$ Equation 3 for the equilibrium condition for firms is a unit cost function in which unit cost must equal product price. If unity is not present, then firms would be expected to move their capital to more profitable cities.

${ }^{9}$ In the theoretical framework of Roback (1982), there is a distinction between productive and unproductive amenities. For example, it is argued that $C_{S}$ can be smaller than zero, implying the cost of an unproductive amenity (e.g., clean air).

10 See Roback (1980) for market-clearing conditions under which wage and rent gradients are influenced by the utility level.
} 
whereas firm equilibrium requires low rents in high-amenity areas to justify firm location ${ }^{11}$. The empirical application of this paper exclusively addresses one side of the equilibrium presented in the Roback framework: individuals and the determinants of their location decisions. Figure 1 shows that at a given wage rate, an inward shift in the quantity of amenities will result in an increase in rental (housing) prices. Thus, when holding the wage constant, we should observe a positive effect from the quantity of amenities on housing prices in the respective city.

Certain aspects of the framework deserve careful treatment. First, Roback (1982) argues that firms will want to be located in places with lower rental cost, as depicted earlier in the cost function for firms. Given that individuals seek to live in high-amenity places, they must be compensated with higher wages at lowamenity places to achieve the same utility. But the cost function for firms in this framework has strict assumptions. Firms are assumed to operate under constant returns to scale. Additionally, capital is perfectly mobile and will thus be equally profitable in different cities. Although scale-related variables such as population density and population growth are introduced as explanatory variables into the empirical application of this framework by Roback (1982), the theoretical framework itself is rather silent regarding the strong correlation between market size and productivity ${ }^{12}$. However, we know from previous research that there is a strong relationship between market size and productivity, both for firms and for individuals (CICCONE and HALL, 1996; PUGA, 2010; COMBES et al., 2012). Another issue with the framework is that amenities are also assumed to be independent of market size. Amenities are primarily considered to be intrinsic to a location (e.g., natural amenities). For that reason, the linear relationship between market size and external amenities such as the size of the retail sector or consumer services is not discussed in this type of framework.

\section{Data, variables and empirical strategy}

Data

The data used in the study are obtained from Statistics Sweden, and they cover a seven-year period for all Swedish municipalities between 2002 and 2008. The data are used to perform fixed-effect estimations and are used for maps that display the overall spatial patterns prior to the estimation results. The map below serves a descriptive purpose and shows the Swedish municipalities, which represent the respective geographical aggregation used. In Sweden, there are 290 municipalities, each of which belongs to one of 81 local labor markets. The map is shaded with respect to population density in each municipality, and the dots represent the spatial distribution of stores to provide an overview. The strong relationship between population density and the availability of stores is evident in the map. We observe a clustering of stores in

\footnotetext{
${ }^{11}$ Roback (1982) distinguishes between productive and unproductive amenities. The argument is that when the amenities in an area are productive, the rents would rise, although the change in wages would be ambiguous.

12 Population density, for example, is treated as a form of amenity, the effect of which is expected to be reflected in wage levels in the empirical application of this framework. However, the results for this relationship are found to be insignificant.
} 
the southern part of the country, especially around the three metropolitan regions, Stockholm, Malmö and Gothenburg. In addition, the map signals some regional dependencies that require careful treatment in an empirical setting.

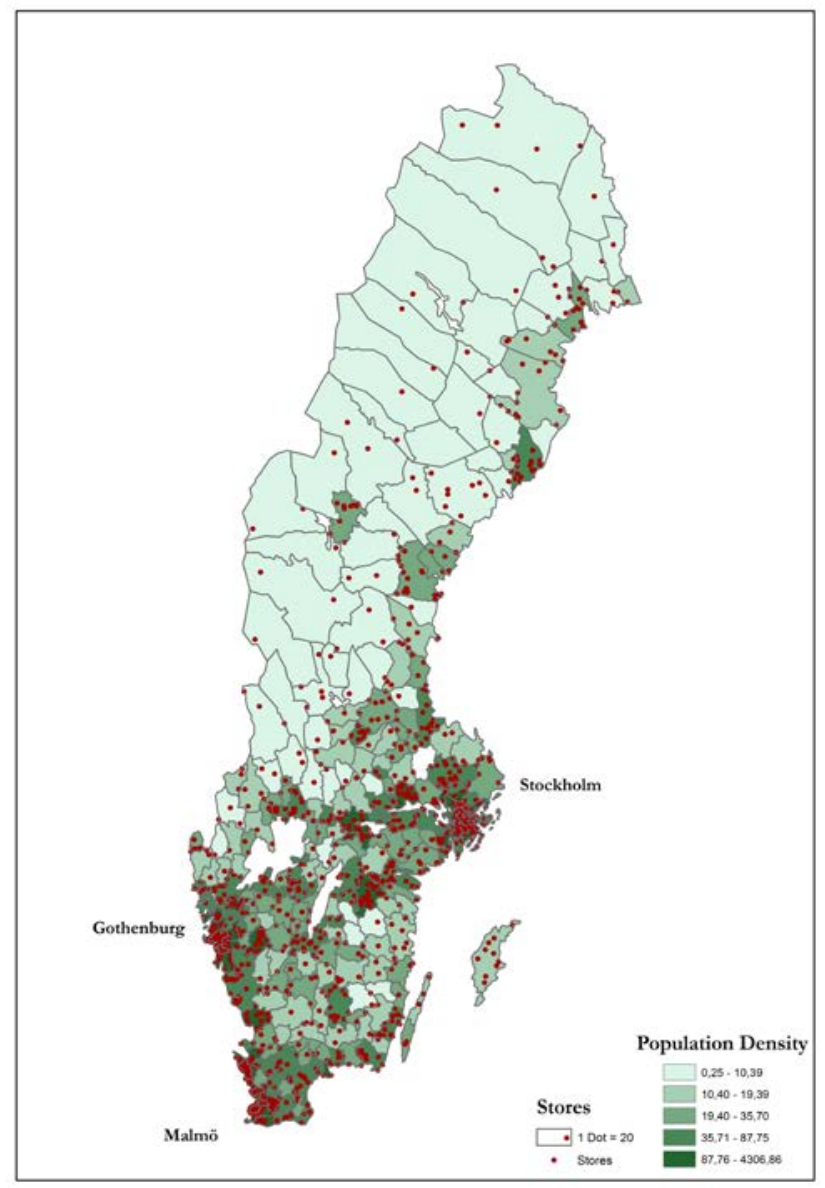

Figure 2: Swedish municipalities and the distribution of stores across Sweden

\section{$\underline{\text { Variables }}$}

Q ratio: The theoretical framework relates house prices in a location to its attractiveness. Estimating an accurate hedonic model for house price variation across space requires access to a detailed set of microdata in which the effect from house characteristics can be separated from the effects of spatially bounded characteristics (i.e., the neighborhood level for within-city variation or the city level for an across-city spatial equilibrium framework). In the absence of micro-data, one method of examining across-city variation in place attractiveness is to investigate average house prices per municipality. But municipal averages for house prices per square meter may lead to coarse results if the cost of construction is not adjusted. Because house prices vary across spaces, the cost to construct a house should also vary because of differences in the composition of residents and in the economic structure of these municipalities. The Q ratios used in this study are calculated by Berg and Berger (2006) on the municipal level for the Swedish 
housing market based on Tobin's Q theory of investment ${ }^{13}$. His investment theory builds on the idea that investment should be related to a ratio between the marginal value of capital and the marginal replacement cost (BRAINARD and TOBIN, 1968; TOBIN, 1969). The implementation of such a ratio for a homogenous housing market would thus suggest that if the marginal price of a house in the market is higher than its marginal production cost, then construction firms are incentivized to build new dwellings (which would mean that the Q ratio would be greater than 1). Likewise, incentives for production should disappear when $\mathrm{Q}$ is equal to or smaller than 1 because of evaporating profit margins. The theoretical framework discusses how house prices should reflect people's willingness to reside in a certain municipality. If we read the $\mathrm{Q}$ ratio from this perspective, then we can state that the ratio also reflects excess demand (supply) in a market, where a $\mathrm{Q}$ ratio equal to 1 reflects an equilibrium condition. By the same token, a Q ratio larger (or smaller) than 1 implies a state out of equilibrium.

The average Q ratios for Swedish municipalities are calculated by Berg and Berger (2006), who estimate the $\mathrm{Q}$ ratio as the ratio between the price index for quality-adjusted prices for owner-occupied houses and construction prices, which are adjusted for subsidies that reduce the production cost. Berg and Berger (2006) calculate the numerator of the $\mathrm{Q}$ ratio as the quality-adjusted price per square meter, with the price being adjusted for the age of the house and appreciating by one percent every year since the house was built ${ }^{14}$. A $Q$ ratio higher than one implies excess demand in the respective housing market such that construction firms have an incentive to build new houses because of high profit margins. When $\mathrm{Q}$ is equal to one, one can argue that there is an equilibrium situation in the respective market. Likewise, a $\mathrm{Q}$ ratio lower than one should imply excess supply such that profit margins evaporate for construction firms. The manner in which the $\mathrm{Q}$ ratio signals the state of supply and demand in the housing market in a municipality makes it a good measure to use as a proxy for place attractiveness because it is directly linked to the willingness of people to pay for housing in a municipality while accounting for variations in the cost structure.

The two following maps in Figure 3 and 4 display the variation in Q ratios and the variation in average house prices per square meter across Swedish municipalities. The two variables show an 80 percent correlation. Although the variables are highly correlated, the maps show small differences in how these values reveal themselves spatially. The map on the left-hand side showing the spatial distribution of $\mathrm{Q}$ ratios is shaded such that the red municipalities are those with a $Q$ value equal to or higher than 1 , implying a state of equilibrium or excess demand. With $\mathrm{Q}$ ratios larger than one, only the three metropolitan regions appear to have a notable regional pattern, where several municipalities in the same region have $\mathrm{Q}$ ratios larger than one. One can also observe other municipalities with high $\mathrm{Q}$ ratios in

\footnotetext{
${ }^{13}$ Despite the appropriateness of $\mathrm{Q}$ theory for housing investment, there is only a limited amount of previous empirical work utilizing this theory. (Takala and Tuomala (1990) for Finland and Jud and Winkler (2003) for the US argue that the Q ratio is a significant determinant of housing investment. Jaffe (1994) also reports a positive correlation between the Q ratio and housing investment in Sweden.)

${ }^{14}$ See Berger (2000) for details regarding the calculations of the Q ratio and Berger et al. (2000) for details on the calculation of the present value of housing subsidies.
} 
other parts of the country (e.g., the two major cities in the Northern part, Umeå and Luleå), where economic activity and population density are distinctively higher than the country average. Both maps show that it is possible to observe some municipalities with low $\mathrm{Q}$ ratios and low housing values around the City Municipalities with high Q ratios and high housing prices despite their relative proximity, with the exception of the three metropolitan regions. This situation signals that the spillover effects generated by the market conditions in the large central city municipalities are sharply attenuated when we examine the municipalities in the bordering regions.

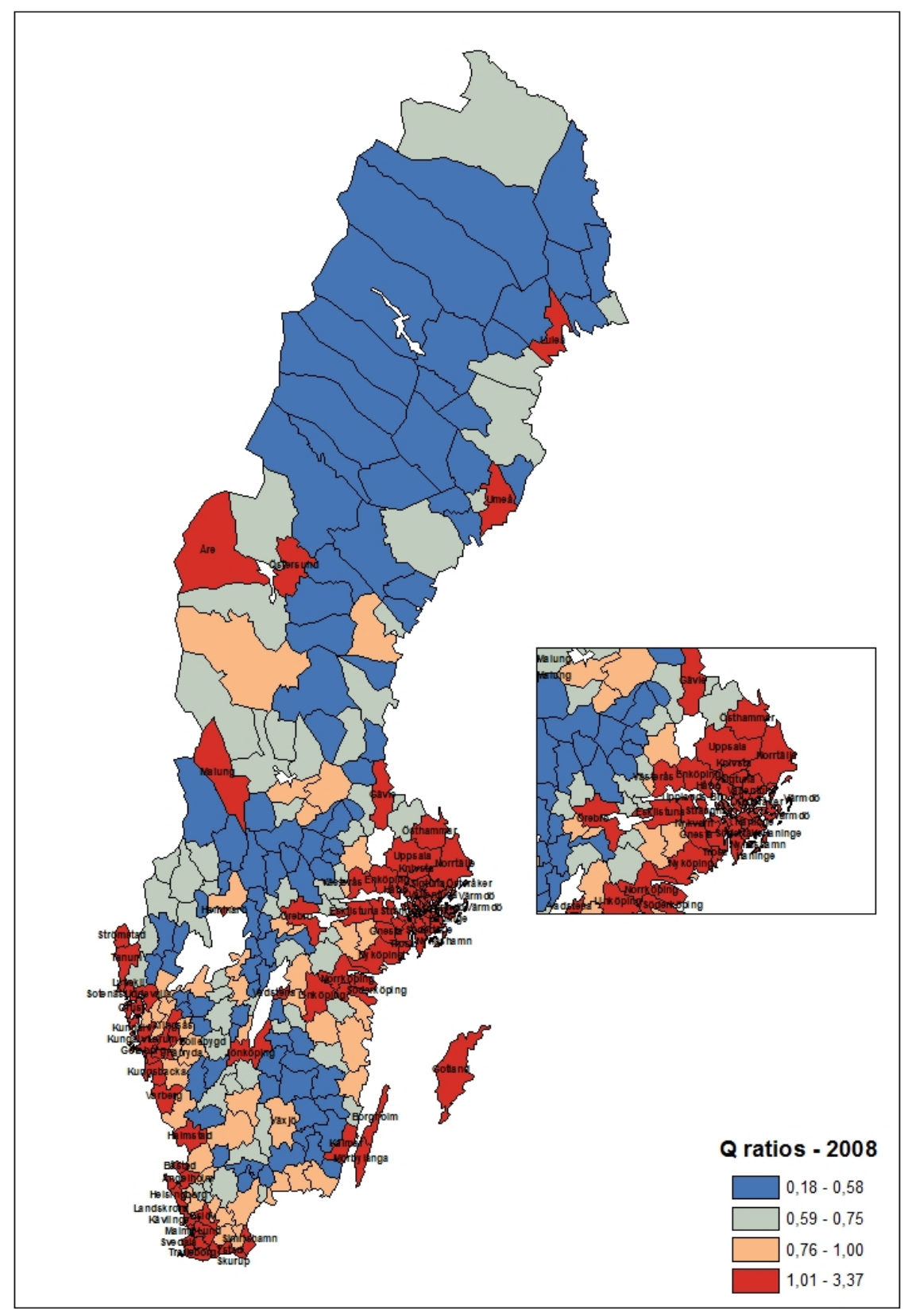

Figure 3: The spatial variation in $Q$ values across Swedish municipalities 


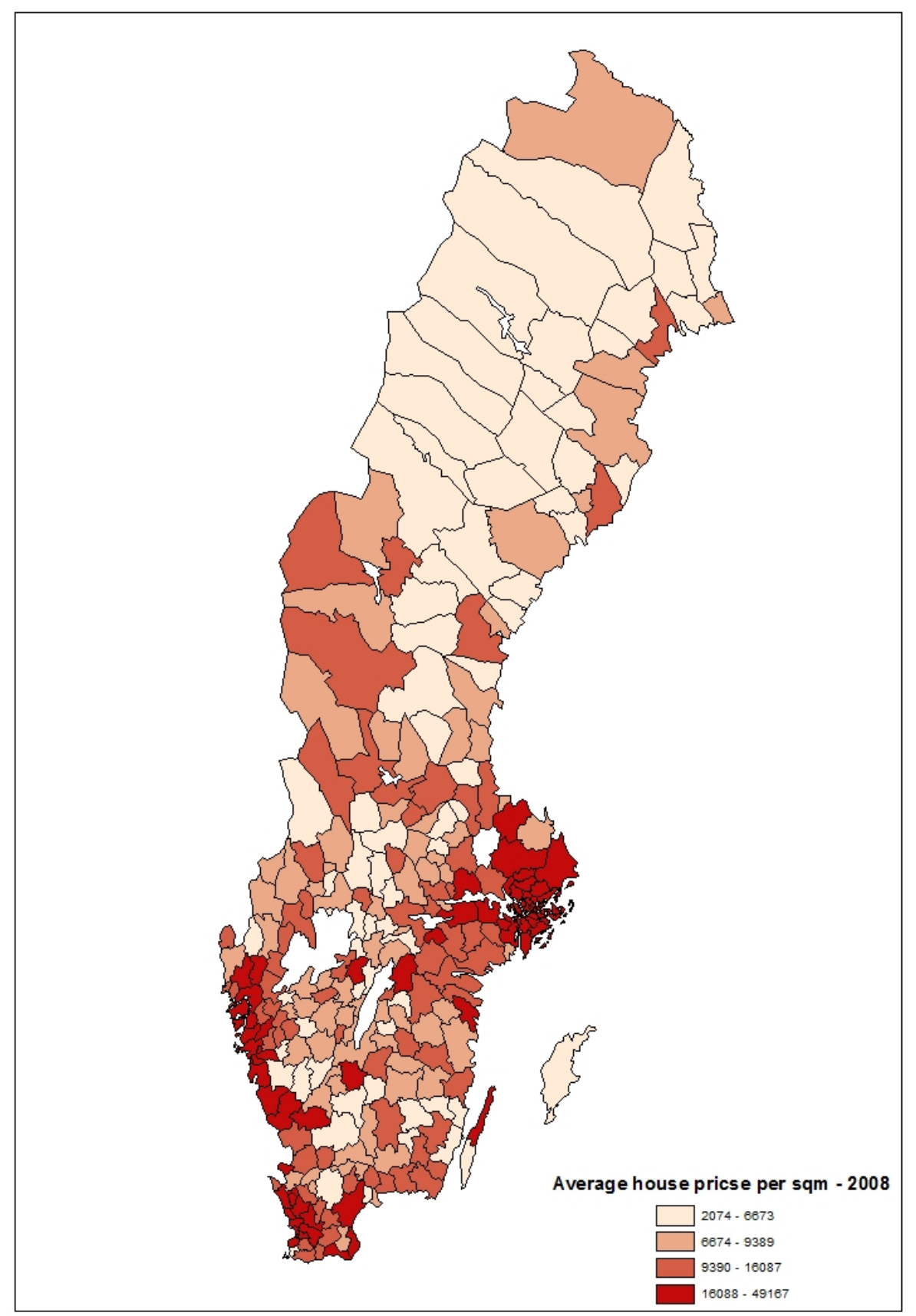

Figure 4: The spatial variation average house prices per sqm in Swedish municipalities

Access to shops: The variables representing accessibility to retailers (shops) in municipalities and in regions are the variables of interest. The aim is to capture the relevance of a retail market in close proximity to the attractiveness of cities and rural municipalities. The paper uses an accessibility measure to calculate store potential in a municipality, considering not only the number of stores but also time distances. 
Calculations are performed based on the earlier work of Johansson, Klaesson and Olsson (2002), which is further developed by Johansson and Klaesson (2011), investigating the agglomeration dynamics of business services. The total retail accessibility for each municipality can be expressed as shown below in equation 4. By calculating the accessibility to retail, we account for not only the stores in the respective municipalities but also the stores that are located in neighboring municipalities that are hosted in the same region (the 81 Swedish local labor markets). The reason is that, spillover effects across municipal boundaries within the same region almost certainly exist; thus, the total shop accessibility consists of two separate measures, one for access to shops in the respective municipality, and one for access to shops in the region where the municipality is located. We know that for a fair share of retailing activities, the relevant market boundaries extend beyond the municipal borders (ÖNER, 2013). In equation 4, $A S_{m}^{M}$ accounts for intra-municipal retail accessibility, and $A S_{m}^{R}$ accounts for intra-regional retail accessibility.

The calculations are performed as shown below, where $S_{m}$ denotes the number of shops in municipality $m$ and $S_{R}$ denotes the number of shops in hosting region $\mathrm{R}$, excluding those in municipality $m$. The distance decay parameters in the equations are denoted by $\lambda$, and they have different values for the municipality and the region ${ }^{15}$. The travelling time within the municipality is denoted by $t_{m m}$, and $t_{m R}$ denotes the traveling time between municipality $m$ and other municipalities in the same region ${ }^{16}$.

$$
\begin{array}{ll}
\text { Access to shops in municipality: } & A S_{m}^{M}=S_{m} e^{\left\{-\lambda_{M} t_{m m}\right\}} \\
\text { Access to shops in region: } & A S_{m}^{R}=\sum_{R-m} S_{R} e^{\left\{-\lambda_{R} t_{m R}\right\}}
\end{array}
$$

Accounting for distance decay is particularly important for this type of framework because it allows us to control for spatial dependencies and to account for a spatial continuum (ANDERSSON and GRÅSJÖ, 2009). The retail markets are not separated with visible boundaries. In fact, with varying sensitivities to distance depending on the type of retailing in question, consumers patronize not only the closest stores but also those that are located farther from their immediate market (LARSSON and ÖNER, 2014). Thus, it is reasonable to assume that the amenity effect from these shops should function in the same manner. The types of consumption possibilities that exist in the region (in excess of the retail potential in a municipality) should also be relevant, especially for city municipalities but less so for rural municipalities.

One problem with such measures is that access to shops in municipality and region are highly correlated with the size of the respective municipal market. Size, as measured in terms of Population density, has a correlation with Access to shops in municipality of approximately 0.6 and a correlation with Access to shops in region of 0.7. As the variables of interest of the study, Access to shops in municipality and Access to shops in region (denoted as $\mathrm{AS}_{\mathrm{M}}$ and $\mathrm{AS}_{\mathrm{R}}$ ) are highly driven by market size. In large markets (densely populated cities), we naturally observe a larger number of shops. This observation indicates that if one examines the influence

\footnotetext{
${ }^{15}$ Distance decay parameters are calculated by Johansson et al. (2002) using real commuting data among the Swedish municipalities.

16 Travel time by car is used here.
} 
of available stores within a certain area on place attractiveness, this influence may merely reflect the size effect. The estimation of a model that introduces market size and access to shops variables as explanatory variables is problematic because of this high correlation between market size and the size of the retail market. This situation challenges any causal claim and risks the robustness of the estimations. Therefore, following the approach ${ }^{17}$ proposed by Elton and Gruber (1991), the linear relationship between market size (population density) and retailing in the analysis is eliminated by the orthogonalization of this variable against Population Density. Two side regressions are performed for (i) access to shops in municipality and (ii) access to shops in region on the population density variable, and the residuals ${ }^{18}$ of these side regressions are introduced into the empirical model as orthogonalized access to shops variables ${ }^{19}$. Therefore, the results obtained for the retail variable reflect the relevance of retailing for housing prices (place attractiveness) that do not relate to market size. Thus, the coefficients obtained for these two variables should be interpreted as indicating the relationship between access to shops and Q ratio beyond the effects driven by market size.

The two maps shown below in Figure 4 are obtained by two separate geographically weighted regressions (GWRs) performed for the year $2008^{20}$ and are used for descriptive purposes. A global regression model estimates the average coefficients, whereas a GWR allows the estimated coefficient to vary from location to location ${ }^{21}$. Thus, the model used behind these maps weights the $\mathrm{Q}$ ratios using their proximity to other $\mathrm{Q}$ ratios in the sample. The first map is the visual outcome of the first regression, in which the dependent variable is the $\mathrm{Q}$ ratio and the explanatory variable is Access to stores in municipality. The second map is the visual outcome of the regression in which the $\mathrm{Q}$ ratios are run against the Access to Stores in Region. The maps assist in depicting the spatial heterogeneity and differences in the relationship between (i) access to shops in the municipality and Q ratios and (ii) access to shops in the region and Q ratios. This visual representation supports the argument that the two 'access to stores' variables are complementary measures, although their relationships to place attractiveness as proxied by the $\mathrm{Q}$ ratio differ from one another.

Figure 5 maps the coefficients obtained from the two GWRs according to a range of standard deviations (as shown in the map legends). In the maps, the municipalities that are shaded with red tones represent relatively high estimated coefficients (with respect to the average) obtained for the relationship between the access to stores measures and the $\mathrm{Q}$ ratios. The municipalities that are shaded with blue tones represent relatively lower estimated coefficients (with respect to the average). In both maps, there are only a few clusters for which large marginal effects appear for several municipalities located in close proximity to one another, with the exception of the municipalities located in the three metropolitan regions

\footnotetext{
17 Application of the orthogonalization approach can also be found in the works of Kim Karlsson (2012) and Hacker et al. (2014). 18 After discriminating the linear relationship, we observe that the correlation between population density and access to shops in municipality as well as access to shops in region is naturally zero.

19 Side regressions are performed via pooled OLS estimations.

${ }^{20}$ Regressions are run by GWR for the year 2008 using ArcGIS utilizing Euclidian distances. The AICc bandwidth method is selected.

${ }^{21}$ FOTHERINGHAM et al. (2002)
} 
(Stockholm, Gothenburg and Malmö). However, we can observe some clusters of low marginal effects when we examine the inner parts of the country and, in some cases, parts in rather close proximity to the metropolitan areas. These two maps show that in a majority of the cases, when a municipality has a positive relationship between the Q ratio and access to stores in the same municipality, it has the same type of relationship between the $\mathrm{Q}$ ratio and accessibility to stores in the region. However, examining the maps in detail, one can observe that there are certain variations between the two maps. Shifting from the first map to the second map, we observe that in some cases, (i) municipalities have a stronger/weaker relationship between the $\mathrm{Q}$ ratio and access to stores in the region compared with the relationship between the $\mathrm{Q}$ ratio and access to stores in the municipality, whereas in other cases, (ii) a strong relationship between $\mathrm{Q}$ ratio and access to stores in the municipality does not appear to be notably different from the average when we examine the relationship between $\mathrm{Q}$ ratio and access to stores in the region (vice versa).
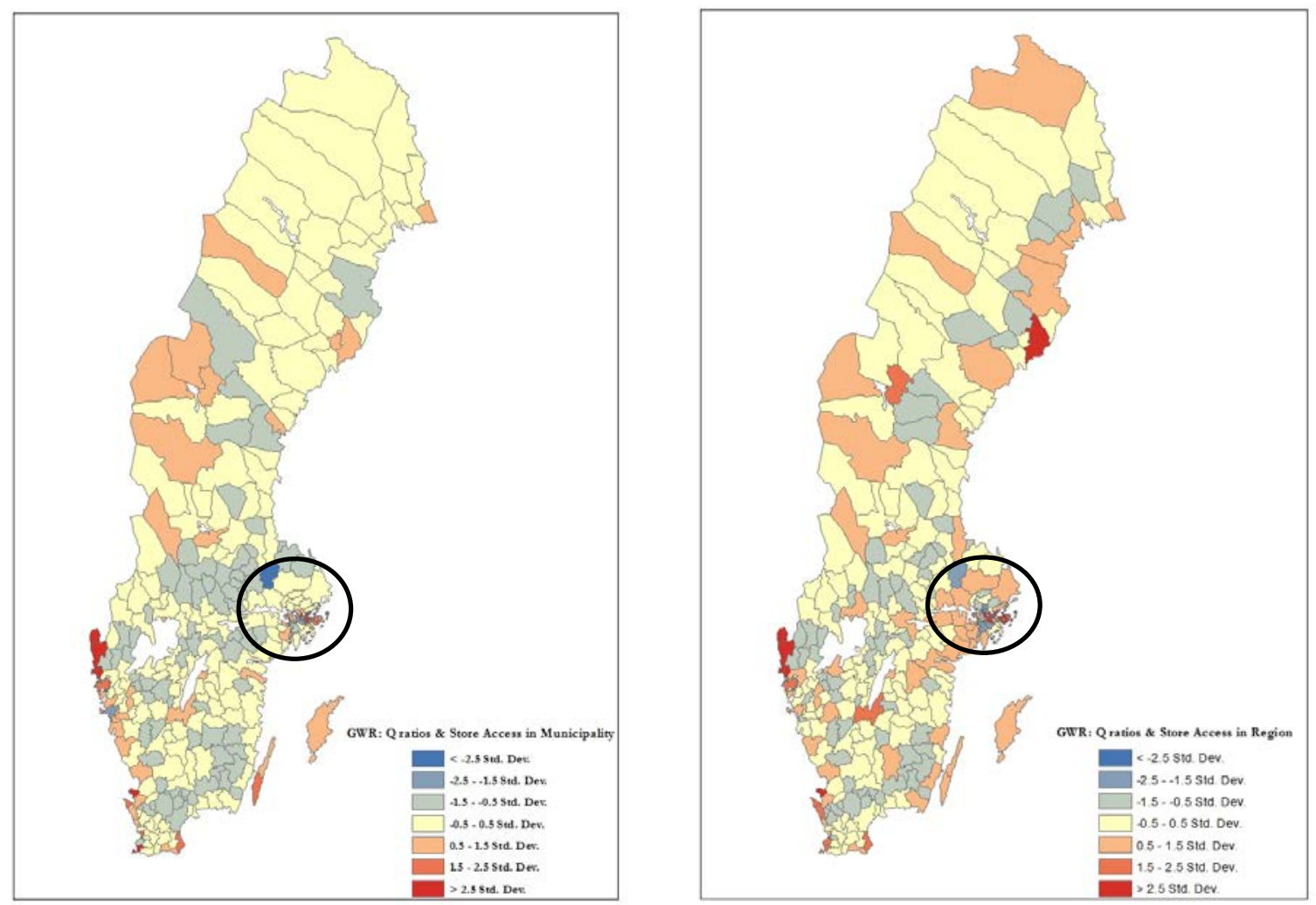

Figure 5: Spatial variation in Q ratios with respect to Access to shops in Municipality (left) and Access to shops in Region (right)

For example, if we examine the Stockholm region (circled in both maps), we see that for the municipalities surrounding inner Stockholm, the relevance of store access in municipalities to their place attractiveness is not significantly different from the country average. By contrast, the second map shows that for these municipalities, the relationship between the $\mathrm{Q}$ ratio and access to stores in region has a marginally stronger relationship than the country average. The observation indicates that for relatively small and peripheral 
municipalities, the consumption possibilities in the region may be more relevant to their attractiveness than those available in close proximity.

Population Density: In the work of Roback (1982), population density is introduced to the empirical application as a form of amenity, the effect of which is found to be insignificant (i.e., the effect on wage levels when amenities are held constant). In this paper, population density is treated as a control for market size and is used for the orthogonalization of the Retail Access variable. Examining the number of people per square kilometer is much more accurate than accounting for the population as a whole because the influence of population density on housing prices should be much greater than alternative market size measures. It is expected that most of the variation in housing prices will be explained by population density. The variable is not only a size control; it also relates to the scale advantages that are discussed under spatial externalities in the theoretical framework.

Mean Wages: The average wage in a municipality is one of the primary components of the spatial equilibrium framework. The relationship between wage levels and place attractiveness is expected to be positive and significant in all cases and is expected to be stronger for rural municipalities than for city municipalities based on theory, indicating that the demand for residence in low-amenity places should be compensated with a slightly higher wage when controlling for all other factors. The variable is also log transformed.

Leisure service concentration: Establishments providing leisure and recreation-related services are summed and divided by the total number of establishments in a municipality to obtain a measure of the concentration of these services. The services that are included in this variable are hotels, restaurants, bars, movie theatres, arts, fair centers and amusement parks, libraries, museums, sports establishments, and beauty- and wellness-related services. Because leisure service concentration is a share variable, it represents the relative importance of these services with respect to the size of the respective municipality.

Municipal Tax: Municipal tax rates are expected to exhibit a negative effect on place attractiveness based on 'voting with your feet' types of arguments, such as that found in Tiebout (1956). Rational individuals are expected to leave places with less attractive local public goods and move to places with more attractive local public goods. Higher tax levels may imply a relatively higher cost for what is provided locally and may have a negative effect on place attractiveness. However, tax levels could have a positive relationship with place attractiveness if they are highly correlated with investments in the municipality that contribute to attractive assets in space.

Unemployment share: The share of the population that is unemployed is introduced to the analysis to control for overall labor market conditions. In the Roback (1982) framework, the effect of unemployment on wage levels is found to be consistently insignificant. Thus, a similar result may also emerge in this study for the effect on the Q ratios. 


\section{Empirical strategy}

The empirical design of the paper is rooted in the spatial equilibrium framework. Theory suggests that excessive demand in the housing market should reflect a high level of place attractiveness, which is largely a product of a place's amenities. The empirical design provides a regression analysis to determine the actual effect of access to shops on place attractiveness. The variables of interest, Access to shops in municipality and Access to shops in region, are denoted by $\mathrm{AS}_{\mathrm{M}}$ and $\mathrm{AS}_{\mathrm{R}}$, respectively, in the model below. The goal is to capture the relationship between access to retailers (shops) and Q ratios, as they proxy for place attractiveness in the respective Swedish municipalities and are denoted by Q in the model. Market scale is controlled by Population Density, denoted by PD. As part of the theoretical framework, average wage levels in municipality $m$ at time $t$ are controlled for and denoted by $W$ in the model. $Z_{m, t}$ is a vector of spatial characteristics for a given municipality $\boldsymbol{m}$ at a given year $\boldsymbol{t}$, which controls for the concentration of leisure services, unemployment rate and tax levels. The analysis is conducted using fixed-effect estimation to isolate place-specific characteristics that are not time variant. Most of the natural, historical and cultural amenities are intrinsic to the municipalities in question and are time invariant; their effects are absorbed by the fixed-effect error term $u_{m}$. Dt denotes the year dummies introduced in the model.

$Q_{m, t}=\alpha+\beta \ln A S_{M, t}+\gamma \ln A S_{R, t}+\delta \ln P D_{m, t}+\emptyset \ln W_{m, t}+Z_{m, t}^{\prime} \rho+D t+u_{m}+\varepsilon_{m, t}$

Based on the theoretical discussions, one could also argue that the amenity effect should also be evident in the wage levels. However, the effect of amenities is much more capitalized in housing prices than in wage levels (Nilsson, 2013). Therefore, any change in the set of amenities in space should be reflected in housing prices more rapidly and more notably than in the wage levels.

One of the most important novelties of the paper in hand is that the empirical practice is conducted for city and rural municipalities. The division is made based on a classification offered by the Swedish Board of Agriculture $^{22}$ and is described and used by Westlund (2011) and Westlund et al. (2014): i) metropolitan municipalities (municipalities in the functional regions of Stockholm, Gothenburg and Malmö), ii) urban municipalities (regional centers outside of metropolitan areas and their 'suburb municipalities'), iii) rural municipalities (municipalities not part of (i) or (ii) with a population density greater than five people per $\mathrm{km}^{2}$ ), and iv) sparsely populated rural municipalities (population density below 5 people per $\mathrm{km}^{2}$ ). The metropolitan municipalities and urban municipalities in this study are grouped together under one category called CITY municipalities, and the rural and sparsely populated rural municipalities are grouped under the category RURAL municipalities.

\footnotetext{
${ }^{22}$ For further information, see http://jordbruketisiffror.wordpress.com/definitioner/landsbygder-och-stader/.
} 
The City municipalities are expected to have a strong relationship with access to shops in close proximity because they attract not only domestic consumers but also consumers from the surrounding municipalities. The relative scale of the available consumption possibilities with respect to the size of these municipalities should be larger. It is expected that the consumption possibilities in the region are relevant to Rural municipalities rather than the consumption possibilities in the immediate market (municipality). Their scale may secure only a certain degree of a retail market, a major part of which then serves domestic consumers. A certain share of the residents in these municipalities is likely to be composed of commuters, who then benefit not only from what is available in close proximity but also from what is available in the region. Urban-periphery interaction suggests that the demand from consumers located in rural-peripheral markets is likely to inflow to central and larger markets but that the reverse is unlikely.

\section{Examining the relationship between place attractiveness and access to shops}

To elaborate further on the relationship between retail shops and place attractiveness, the appropriate estimation technique is to use a within estimator, which will track changes over time rather than accounting for level effects. Such estimation is particularly useful to eliminate the effect from the timeinvariant characteristics of municipalities ${ }^{23}$. Examining place attractiveness through housing prices is challenging given that one must control for every place-specific asset to capture the actual effect of the variable of interest. The effects of, for example, a municipality having a coastal border, being in the center of the region, being in a metropolitan region, having a border with Norway, having one or more historical monuments, having a substantial amount of open space or having a certain type of climate on housing prices can then be captured using the municipality-specific time-invariant component of the composite error term (as shown in the empirical strategy above).

The maps presented previously for descriptive purposes flag the spatial dependencies among the municipalities that are hosted in the same region. The possible effects of these spatial dependencies are mitigated by local labor market clustered standard errors ${ }^{24}$, and the manner in which the retail access variables are constructed also mitigates the spatial dependencies for the municipalities located in the same region.

Table 1 shows the results from the fixed-effects estimation ${ }^{25}$. A large portion of the $\mathrm{R}^{2}$ values comes from the variable Population Density, as population inflow appears to be one of the main determinants of place attractiveness proxied by increasing $\mathrm{Q}$ ratios. The results obtained for Access to shops in city, Access to shops in

\footnotetext{
${ }^{23}$ However, there may still be a set of variables that are time variant and omitted from the analysis, which raises concerns regarding endogeneity. The interpretation of the results avoids casual claims.

${ }^{24}$ The effect of variables such as Mean Wage and Tax levels was previously significant at the one percent confidence level, but they are insignificant when standard errors are clustered across the local labor markets. These results imply that spatial dependence is largely relevant for the wage and tax levels of municipalities sharing the same local labor market, whereas no change in the significance of Population Density and Retail Access is observed.

${ }^{25}$ The coefficients in the regressions are statistically significantly different from each other.
} 
region, Population Density and Average Wage are elasticities. Again, the Access to shops in municipality and Access to shops in region variables are orthogonalized against Population Density, and the linear relationship between the two is discriminated by running regressions and saving the residuals obtained from these regressions. In that sense, the access to shops measures can be considered to be 'size adjusted'. In other words, the result for these variables (access to stores in municipality and access to stores in region) indicates the relationship between consumption possibilities and place attractiveness for the respective municipalities beyond the effects resulting from their size.

Although the attributes of fixed-effect estimations mitigate unobserved variable bias in which timeinvariant effects are eliminated, the analysis still avoids drawing causal claims by acknowledging that many relevant characteristics of these municipalities may still be time variant and omitted from the analysis (or otherwise indistinguishable from increases in retail). (See the appendix for descriptive statistics and pairwise correlations.)

Table 1: The relationship between store access and place attractiveness

\begin{tabular}{llcc}
\hline & All Municipalities & City Municipalities & Rural Municipalities \\
& $\mathrm{Q}$ & $\mathrm{Q}$ & $\mathrm{Q}$ \\
\hline & & & \\
Access to shops in municipality & $0.0305^{*}$ & $0.0924^{* *}$ & 0.0171 \\
& {$[0.0177]$} & {$[0.0406]$} & {$[0.0181]$} \\
Access to shops in region & $0.124^{* *}$ & $0.355^{*}$ & $0.0780^{* *}$ \\
& {$[0.0532]$} & {$[0.205]$} & {$[0.0332]$} \\
Population density & $2.679 * * *$ & $3.882^{* * *}$ & $2.225^{* * *}$ \\
& {$[0.536]$} & {$[1.018]$} & {$[0.272]$} \\
Average wage & $0.784^{* * *}$ & $0.513^{* * *}$ & $0.747^{* * *}$ \\
& {$[0.0602]$} & {$[0.149]$} & {$[0.0623]$} \\
Leisure service concentration & 0.281 & 0.463 & 0.239 \\
& {$[0.200]$} & {$[0.428]$} & {$[0.267]$} \\
Municipal tax rate & -0.0358 & -0.114 & 0.0132 \\
& {$[0.0433]$} & {$[0.0772]$} & {$[0.0137]$} \\
Unemployment share & -0.0729 & -0.669 & 0.432 \\
& {$[0.990]$} & {$[2.331]$} & {$[0.533]$} \\
\hline Year dummies & Yes & Yes & Yes \\
Municipality fixed effects & Yes & Yes & Yes \\
\hline Observations & 2,029 & 650 & 1,379 \\
R-squared & 0.486 & 0.502 & 0.519 \\
Number of municipalities & 290 & 93 & 197 \\
\hline Robust standard error & &
\end{tabular}

Robust standard errors in parentheses $* * * \mathrm{p}<0.01,{ }^{* *} \mathrm{p}<0.05,{ }^{*} \mathrm{p}<0.1$

Standard errors are clustered at the level of local labor markets (Moulton, 1990)

Coefficients are statistically significantly different from one another.

The first regression is run for all Swedish municipalities. Estimated coefficients in the first regression for the relationship between Access to shops in municipality and Access to shops in region and the $\mathrm{Q}$ ratios are consistent with the argument that consumption possibilities in a municipality and in the hosting region are positively related to place attractiveness beyond size effects. The relative importance of consumption 
possibilities in the region for place attractiveness appears to be much stronger than the importance of consumption possibilities in the municipality.

Interesting results are revealed when we examine the two separate regressions for City and Rural municipalities. In city municipalities, both access to shops in the municipality and access to shops in the region are positively related to place attractiveness. This relationship is notably stronger for the consumption possibilities in the region compared with those available in close proximity. By contrast, in rural municipalities, there appears to be no significant relationship between access to shops in the municipality and place attractiveness, although the results are consistent with the earlier argument that what is important for rural municipalities is the available consumption possibilities in the region rather than what is available only in the municipality.

The relationship between the Q ratios and the average wages in city municipalities is slightly weaker than it is for the rural municipalities, a finding that is also consistent with the earlier theoretical discussion. When the changes in other variables are held constant, any change in the wage level in rural municipalities appears to have a larger effect on place attractiveness as represented by the $\mathrm{Q}$ ratios. In both rural and city municipalities, all other control variables, leisure service concentration, municipal tax rate and unemployment, reveal no significant relationship.

\section{Concluding remarks}

Amenities, in broad strokes, refer to place-specific assets that are known to contribute to a city's or region's attractiveness. Previous literature addresses the importance of such assets for regional growth and development in detail. This paper specifically investigates the importance of retailing to place attractiveness. The primary question addressed in the paper is whether the presence of retailers can be considered an amenity. Following a spatial equilibrium framework, an empirical investigation is conducted to capture the relationship between accessibility to stores in municipalities and in regions and place attractiveness as proxied by Tobin's Q ratios for housing investment in Swedish municipalities. The analysis not only accounts for the absolute number of stores but also considers these stores' accessibility. Using distance decay parameters in the calculation of retail accessibility, this analysis also considers the spatial continuum of the retail market. For both for rural and city municipalities, the results signal a significant relationship between the place attractiveness of a municipality and the consumption possibilities in the labor market region where the municipality is located. The consumption possibilities available in close proximity are not found to be relevant to rural municipalities, whereas a positive relationship is observed between consumption possibilities in close proximity and place attractiveness for city municipalities. In addition to retail access, population density is found to explain a large share of the 
variation in the $\mathrm{Q}$ ratios. When the other attributes are held constant, any change in the wage levels appears to have a stronger effect on place attractiveness in rural municipalities than in city municipalities.

This paper contributes to the existing literature on retail location and the importance of amenities for place attractiveness by investigating the relative importance of retail for place attractiveness when accounting for the size effect. The finding that a notable portion of the variation in place attractiveness across cities is explained by retail access suggests the multidimensional importance of the sector. This paper argues that the function of the retail sector extends beyond a simple supply and demand relationship. Many attributes of retail markets are planned and regulated by public authorities, which makes this line of analysis particularly relevant for decision makers, as the indirect effects of having a certain scale of retail market are highlighted.

\section{References}

ALONSO, W. (1964) Location and land use. Toward a general theory of land rent, Harvard University Press, Cambridge, MA.

ADAIR, A., MCGREAL, S., SMYTH, A., COOPER, J. and RYLEY, T. (2000) House prices and accessibility: The testing of relationships within the Belfast urban area, Housing studies 15, 699-716.

ANDERSSON, A. E. (1985) Creativity-The Future of Metropolitan Regions, Prisma, Stockholm.

ANDERSON, S. T. and WEST, S. E. (2006) Open space, residential property values, and spatial context, Regional Science and Urban Economics 36, 773-789.

ANDERSSON, A. E. and ANDERSSON D. E. (2006) The economics of experiences, the arts and entertainment, Edward Elgar Publishing, Cheltenham.

ANDERSSON, M., KLAESSON, J. and LARSSON, J. P. (2013) The sources of the urban wage premium by worker skills: Spatial sorting or agglomeration economies?. Papers in Regional Science.

ANDERSSON, D. E. (1997) Hedonic prices and center accessibility: conceptual foundations and an empirical hedonic study of the market for condominium housing in Singapore, Doctoral dissertation, KTH.

ANDERSSON, D. E., SHYR, O. F. and FU, J. (2010) Does high-speed rail accessibility influence residential property prices? Hedonic estimates from southern Taiwan. Journal of Transport Geography $18,166-174$.

ANDERSSON, A. E. and KARLQVIST, A. (1976) Population and capital in geographical space. The problem of general equilibrium allocation, Computing equilibria: how and why: proceedings of the International Conference organized by the Computing Centre of the Polish Academy of Sciences held in Torun, 183-195.

ANDERSSON, M. and GRÅSJÖ, U. (2009) Spatial dependence and the representation of space in empirical models, The annals of regional science 43, 159-180. 
ARTLE, R. (1959) Studies in the structure of the Stockholm economy, Business research Institute at the Stockholm School of Economics, Stockholm.

BECKMANN, M. J. (1958) City hierarchies and the distribution of city size, Economic Development and Cultural Change 6, 243-248.

BERGER, T. (2000) Tobins q på småhusmarknaden, in T. Lindh (Ed.) Prisbildning och värdering av fastigheter, Institutet för bostads och urbanforskning, Gävle.

BERGER, T., ENGLUND, P., HENDERSHOT'T, P. H. and TURNER, B. (2000) The capitalization of interest subsidies: Evidence from Sweden, Journal of Money, Credit, and Banking 32, 199-218.

BERG, L. and BERGER, T. (2006) The Q theory and the Swedish housing market-an empirical test, The Journal of Real Estate Finance and Economics 33, 329-344.

BRAINARD, W. C. and \& TOBIN, J. (1968) Pitfalls in financial model building, The American Economic Review, 99-122.

BRUECKNER, J. K., THISSE, J. F. and ZENOU, Y. (1999) Why is central Paris rich and downtown Detroit poor? An amenity-based theory, European Economic Review 43, 91-107.

CHESHIRE, P. and SHEPPARD, S. (1995) On the price of land and the value of amenities, Economica 62 , $247-267$.

CHO, S. H., POUDYAL, N. C. and ROBERTS, R. K. (2008) Spatial analysis of the amenity value of green open space, Ecological Economics 66, 403-416.

CHRISTALLER, W. (1933) Die zentralen Orte in Süddeutschland, translated by Carlisle W. Baskin, 1966, as Central Places in Southern Germany, Prentice Hall.

CICCONE, A. and HALL, R. E. (1996) Productivity and the density of economic activity, No. w4313, National Bureau of Economic Research.

CLARK, T. N., LLOYD, R., WONG, K. K. and JAIN, P. (2002) Amenities drive urban growth, Joumal of urban affairs $24,493-515$.

CLARK, T. N. (2003a) The City as an Entertainment Machine, Research in Urban Policy, 9.

CLARK, T. N. (2003b) 3. Urban Amenities: Lakes, opera, and juice bars: Do they drive development?, Research in Urban Policy 9, 103-140.

COMBES, P. P., DURANTON, G., GOBILLON, L., PUGA, D. and ROUX, S. (2012) The productivity advantages of large cities: Distinguishing agglomeration from firm selection, Econometrica 80, 2543-2594.

DES ROSIERS, F., THÉRIAULT, M. and VILLENEUVE, P. Y. (2000) Sorting out access and neighbourhood factors in hedonic price modelling, Journal of Property Investment \& Finance 18, 291 315.

DUBIN, R. A. and SUNG, C. H. (1987) Spatial variation in the price of housing: rent gradients in nonmonocentric cities, Urban Studies 24, 193-204.

FLORIDA, R. (2008) Who is your city? How the creative economy is making where to live the most important decision of your life, Basic Books, New York. 
FOTHERINGHAM, A. S., BRUNSDON, C. and CHARLTON, M. (2002) Geographically weighted regression, Wiley, New York.

GLAESER, E. L. and MARE, D. C. (1994) Cities and skills, No. w4728, National Bureau of Economic Research.

GLAESER, E. L., KOLKO, J. and SAIZ, A. (2001) Consumer city, Journal of economic geography 1, 27-50.

GLAESER, E. L., GYOURKO, J. and SAKS, R. (2005) Why have housing prices gone up?, No. w11129.

National Bureau of Economic Research.

GLAESER, E. L. (2008) Cities, agglomeration, and spatial equilibrium, Oxford University Press, New York.

GIBBONS, S., MOURATO, S. and RESENDE, G. (2011) The amenity value of English nature: a hedonic price approach, SERC discussion paper 74, Spatial Economics Research Center.

GEOGHEGAN, J., WAINGER, L. A. and BOCKSTAEL, N. E. (1997) Spatial landscape indices in a hedonic framework: an ecological economics analysis using GIS, Ecological economics 23, 251-264.

GRAVES, P. E. and LINNEMAN, P. D. (1979) Household migration: Theoretical and empirical results, Joumal of urban economics 6, 383-404.

HACKER, R. S., KARLSSON, H. K. and MÅNSSON, K. (2014) An investigation of the causal relations between exchange rates and interest rate differentials using wavelets, International Review of Economics \& Finance 29, 321-329.

HELSLEY, R. W. and STRANGE, W. C. (1990) Matching and agglomeration economies in a system of cities, Regional Science and Urban Economics 20, 189-212.

ISARD, W. (1956) Location and space-economy, MIT Press, Cambridge, MA.

IRWIN, E. G. (2002) The effects of open space on residential property values, Land economics, 78, 465480.

JAFFEE, D. M. (1994) Den svenska fastighetskrisen (The Swedish Real Estate Crisis), SNS Förlag, Stockholm.

JACOBS, J. (1961) The death and life of great American cities, Random House, New York.

JOHANSSON, B., KLAESSON, J. and OLSSON, M. (2002) Time distances and labor market integration, Papers in Regional Science 81, 305-327.

JOHANSSON, B. and KLAESSON, J. (2011) Agglomeration dynamics of business services, The annals of regional science $47,373-391$.

JUD, G. D. and WINKLER, D. T. (2003) The Q theory of housing investment, The Journal of Real Estate Finance and Economics 27, 379-392.

KIM KARLSSON, H. (2012) Dynamics of macroeconomic and financial variables in different time horizons, $\mathrm{PhD}$ thesis in Economics, Jönköping University.

KRAFFT, M. and MANTRALA, M. K. (Eds.). (2006) Retailing in the 21st century: current and future trends, Springer, Berlin.

LARSSON, J. P. and ÖNER, Ö. (2014) Location and co-location in retail: a probabilistic approach using geo-coded data for metropolitan retail markets. The Annals of Regional Science, 1-24. 
LARSSON, J. P. (2014) The Neighborhood or the Region? Reassessing the density-wage relationship using geocoded data, Annals of Regional Science (forthcoming).

LUCAS, R. E. (2001) Externalities and cities, Review of Economic Dynamics 4, 245-274.

LÖSCH, A. (1940) Die räumliche Ordnung der Wirtschaft, Jena, G. Fischer, English translation (1954): The Economics of Location.

LLOYD, R. and CLARK, T. N. (2001) The city as an entertainment machine, Critical perspectives on urban redevelopment 6, 357-78.

MELLANDER, C., PETTERSSON, L. and ÖNER, Ö. (2011) Culture city, Journal of Town and City Management 2, 246-262.

MOULTON, B. R. (1990) An illustration of a pitfall in estimating the effects of aggregate variables on micro units, The review of Economics and Statistics, 334-338.

NILSSON, P. (2013) Price Formation in Real Estate Markets, Doctoral dissertation, Jönköping University.

ÖNER, Ö. (2013) Returns to Location in Retail: Investigating the relevance of market size and regional bierarchy, No. 336, Royal Institute of Technology, CESIS-Centre of Excellence for Science and Innovation Studies.

PARTRIDGE, M. D., RICKMAN, D. S., ALI, K. and OLFERT, M. R. (2008) The geographic diversity of US nonmetropolitan growth dynamics: A geographically weighted regression approach, Land Economics 84, 241-266.

PUGA, D. (2010) The Magnitude and Causes of Agglomeration Economies, Journal of Regional Science 50, 203-219.

RIVERA-BATIZ, F. L. (1988) Increasing returns, monopolistic competition, and agglomeration economies in consumption and production, Regional Science and Urban Economics 18, 125-153.

ROSEN, S. (1979) Wage-based indexes of urban quality of life, Current issues in urban economics, 3.

ROBACK, J. (1980) The Value of Local Urban Amenities: Theory and Measurement, Ph.D. dissertation, University Rochester.

ROBACK, J. (1982) Wages, rents, and the quality of life, The Journal of Political Economy, 1257-1278.

SÖDERBERG, B. and JANSSEN, C. (2001) Estimating distance gradients for apartment properties, Urban Studies 38, 61-79.

TAKALA, K. and TUOMALA, M. (1990) Housing investment in Finland, Finnish Economic Papers 3, $41-$ 53.

TIEBOUT, C. M. (1956) A pure theory of local expenditures, The journal of political economy 64, 416-424.

TOBIN, J. (1969) A general equilibrium approach to monetary theory, Journal of money, credit and banking 1 , $15-29$.

TYRVÄINEN, L. and MIETTINEN, A. (2000) Property prices and urban forest amenities, Journal of environmental economics and management 39, 205-223.

ULLMAN, E. L. (1954) Amenities as a factor in regional growth, Geographical Review 44, 119-132.

VON THÜNEN, J. H. (1966) The isolated state, Wartenberg, CM trans. Translation of: Der isolierte Staat (1826). 
WEBER, A. (1909) Über den Standort der Industrien, JCB Mohr, Tubingen; translated into English as Weber, A (1929) Alfred Weber's Theory of Location of Industries, University of Chicago Press, Chicago, Illinois.

WESTLUND, H. (2011) Multidimensional entrepreneurship: theoretical considerations and Swedish empirics, Regional science policy \& practice 3, 199-218.

WESTLUND, H., LARSSON, J. P. and OLSSON, A. R. (2014) Start-ups and Local Entrepreneurial Social Capital in the Municipalities of Sweden, Regional Studies, (forthcoming). 
Appendix 1: Descriptive statistics

\begin{tabular}{lcrrrr}
\hline Variable & Obs & \multicolumn{1}{c}{ Mean } & Std Dev & \multicolumn{1}{c}{ Min } & Max \\
\hline ALL & & & & & \\
\hline Q & 2030 & 0.801 & 0.459 & 0.170 & 3.370 \\
Access to shops in municipality & 2030 & 0.000 & 0.865 & -2.303 & 2.346 \\
Access to shops in region & 2030 & 0.000 & 1.219 & -5.165 & 2.930 \\
Ln_Population density & 2030 & 3.331 & 1.623 & -1.427 & 8.368 \\
Ln_Mean wage & 2030 & 11.370 & 0.309 & 10.409 & 12.935 \\
Leisure concentration & 2030 & 0.055 & 0.016 & 0.000 & 0.106 \\
Municipal tax & 2029 & 21.408 & 1.299 & 17.120 & 33.250 \\
Unemployment share & 2029 & 0.020 & 0.007 & 0.005 & 0.054 \\
\hline CITY municipalities & & & & & \\
\hline Q & 650 & 1.186 & 0.475 & 0.380 & 3.370 \\
Access to shops in municipality & 650 & 0.117 & 1.143 & -2.303 & 2.346 \\
Access to shops in region & 650 & 0.076 & 1.238 & -5.165 & 1.983 \\
Ln_Population density & 650 & 4.864 & 1.291 & 2.348 & 8.368 \\
Ln_Mean wage & 650 & 11.378 & 0.440 & 10.409 & 12.935 \\
Leisure concentration & 650 & 0.056 & 0.017 & 0.000 & 0.106 \\
Municipal tax & 650 & 20.697 & 1.278 & 17.120 & 22.800 \\
Unemployment share & 650 & 0.020 & 0.007 & 0.005 & 0.041 \\
\hline RURAL municipalities & \multicolumn{7}{c}{} & \\
\hline Q & 1379 & 0.619 & 0.316 & 0.170 & 2.530 \\
Access to shops in municipality & 1379 & -0.055 & 0.690 & -2.061 & 1.647 \\
Access to shops in region & 1379 & -0.036 & 1.209 & -4.020 & 2.930 \\
Ln_Population density & 1379 & 2.607 & 1.207 & -1.427 & 5.124 \\
Ln_Mean wage & 1379 & 11.366 & 0.223 & 10.833 & 12.170 \\
Leisure concentration & 1379 & 0.054 & 0.016 & 0.000 & 0.100 \\
Municipal tax & 1379 & 21.744 & 1.167 & 18.760 & 33.250 \\
Unemployment share & 1379 & 0.021 & 0.007 & 0.005 & 0.054 \\
\hline
\end{tabular}

Appendix 2: Pairwise Correlations

\begin{tabular}{|c|c|c|c|c|c|c|c|c|}
\hline & Q & AS_mun & AS_reg & (Ln)PopDensity & (Ln)MeanWage & Leisure con & Municipal tax & Unemp share \\
\hline \multicolumn{9}{|l|}{ ALL } \\
\hline Q & 1 & & & & & & & \\
\hline AS in mun & 0.1159 & 1 & & & & & & \\
\hline AS in reg & -0.0513 & -0.5030 & 1 & & & & & \\
\hline Ln_PopDensity & 0.7494 & 0.0002 & -0.0002 & 1 & & & & \\
\hline Ln_MeanWage & 0.1542 & 0.4948 & -0.3838 & 0.1911 & 1 & & & \\
\hline Leisure con & 0.1069 & 0.3778 & -0.3207 & 0.0534 & 0.3112 & 1 & & \\
\hline Municipal tax & -0.5083 & 0.1047 & -0.1679 & -0.5987 & -0.0298 & 0.0803 & 1 & \\
\hline Unemp share & -0.2768 & 0.3544 & -0.3803 & -0.1983 & 0.0754 & 0.2195 & 0.2734 & 1 \\
\hline \multicolumn{9}{|l|}{ CITY } \\
\hline $\bar{Q}$ & 1 & & & & & & & \\
\hline AS in mun & -0.0237 & 1 & & & & & & \\
\hline AS in reg & -0.1458 & -0.6540 & 1 & & & & & \\
\hline (Ln)PopDensity & 0.7325 & -0.0209 & -0.1901 & 1 & & & & \\
\hline (Ln)MeanWage & 0.2435 & 0.6343 & -0.5500 & 0.3190 & 1 & & & \\
\hline Leisure con & 0.0678 & 0.4577 & -0.4155 & 0.0244 & 0.4110 & 1 & & \\
\hline Municipal tax & -0.6380 & 0.1988 & -0.0578 & -0.6743 & -0.0320 & 0.1784 & 1 & \\
\hline Unemp share & -0.3606 & 0.5349 & -0.4535 & -0.1263 & 0.3665 & 0.3111 & 0.3643 & 1 \\
\hline \multicolumn{9}{|l|}{ RURAL } \\
\hline$\overline{\mathrm{Q}}$ & 1 & & & & & & & \\
\hline AS in mun & 0.1925 & 1 & & & & & & \\
\hline AS in reg & -0.0567 & -0.4208 & 1 & & & & & \\
\hline (Ln)PopDensity & 0.5206 & -0.1336 & 0.0433 & 1 & & & & \\
\hline (Ln)MeanWage & 0.0822 & 0.2862 & -0.2692 & 0.1722 & 1 & & & \\
\hline Leisure con & 0.1203 & 0.3242 & -0.2765 & 0.0304 & 0.2418 & 1 & & \\
\hline Municipal tax & -0.1967 & 0.1179 & -0.2207 & -0.4084 & -0.0181 & 0.0676 & 1 & \\
\hline Unemp share & -0.2769 & 0.2294 & -0.3409 & -0.2776 & -0.2065 & 0.1743 & 0.2300 & 1 \\
\hline
\end{tabular}

